\title{
INTIMATE ENGAGEMENTS: A HOLOCAUST LESSON
}

\author{
Laura Levitt
}

These words are dedicated to those who died because death is a punishment because death is a reward because death is the final rest because death is eternal rage

These words are dedicated to those who died. ...

These words are dedicated to those who survived because life is a wilderness and they were savage because life is an awakening and they were alert because life is a flowering and they blossomed because life is a struggle and they struggled because life is a gift and they were free to accept it

These words are dedicated to those who survived. (Irena Klepfisz, "Bashert")

Sometimes the impact of sexual trauma doesn't seem to measure up to that of collectively experienced historical events, such as war and genocide. Sometimes it seems invisible because it is confined to the domestic or private sphere. Sometimes it doesn't appear sufficiently catastrophic because it doesn't produce dead bodies or even, necessarily, damaged ones. (Ann Cvetkovich, An Archive of Feelings ${ }^{2}$ )

It has become no longer fashionable to talk about the lessons of the Holocaust, and in many ways I appreciate this change in critical engagement. I do not 
want to universalize the experiences of those who died and those who survived. That is part of what I find so powerful about the dedications to Irena Klepfisz's poem "Bashert," which begins with two sets of dedications: one to those who died, the other to those who survived. These are long dedications, only portions of which I have excerpted here. They offer similar litanies, lists of reasons for life and of reasons for death. Klepfisz insists that there are no simple answers, no neat lessons to be learned. Despite our desires to master the past, to know what we should have done to survive, there is no way to attain such knowledge. No matter how much we read, how much we see and take in of that past, we cannot possibly protect ourselves from some future danger. What we learn from our engagement with these materials is much more elusive. These truths are much more complicated. As Klepfisz reminds us over and over again in her dedications, the same mechanism that kept one person alive might have been instrumental in the death of another.

Given this, what can it possibly mean to draw lessons from representations of the Holocaust, works like Klepfisz's poem, or images like those of Shimon Attie's "Sites Unseen"? ?hat do we gain from these engagements in the present? In what follows, I attempt to answer these questions by turning inward and looking at how these works might touch us in a more intimate way. I offer no grand claims. Instead, I offer a more intimate lesson that in its specificity might point the way to a different kind of critical engagement. I write personally about my own engagement with some of these works in order to explain what they have taught me.

To write about why I have been so drawn to Holocaust art, film, and especially literature is difficult. I didn't start out approaching these materials in the ways that I engage with them now. They have come to bear different meanings for me. I began to think about Holocaust and representation as a way of resisting approaches to Holocaust materials that I found intolerable. I didn't like Holocaust theology. I wasn't interested in where God was during the Holocaust. I really wanted to know more about where good people of conscience were. I wanted to understand what had happened as all too deeply and frighteningly human. I wanted to figure out what not to do, how I might survive some future onslaught on Jews, and I also, slowly but surely, wanted to look more closely at how and in what ways I might be complicit, how I might be a participant in social and political and cultural processes that could lead to the oppression of other people. I wanted to consider how it might be possible for me either to be like a Nazi or to be complicit as a bystander. 


\section{Laura Levitt}

In the late 1980s, I felt moved by Terrence Des Pres's The Survivor, ${ }^{4}$ a lyrical literary account of what it meant to survive. I found his very careful, unflinching analysis of resistance as a quotidian activity compelling. His was the first text that really offered me an alternative to more overtly heroic accounts. ${ }^{5}$ Armed revolt was not the only form of resistance. For Des Pres, washing one's face in dirty water each day was an act of resistance; resistance included all of those acts that allowed concentration-camp inmates to maintain a sense of their own humanity, acts both grand and small that kept them alive, even for a time. I was also intrigued that Des Pres came to this material as a literary critic. His work made me think again about the power of words and narrative, and how and why careful and close readings matter. From his work, I felt as if I had begun to identify with survivors differently. But I also wanted to think in new ways about perpetrators, about Nazis and what motivated them.

I cannot piece together this chronology very well. It all gets blurred in my memory, but I know that I read a great deal over the summer before I was to teach my first Holocaust course in the fall of 1988. I know that I was interested in resistance and responses to the Holocaust and built the course around these themes. I also know that I read psychoanalyst Alice Miller's For Your Own Good, ${ }^{6}$ but that it was really Christa Wolf's Patterns of Childhood, ${ }^{7}$ an autobiographical novel about growing up German under the Third Reich, that helped me think about what it meant to become a Nazi. I was able to identify with Nelly, the protagonist of the novel, and her need for approval. I was able to connect with her desire to be a good girl - in this case, a good Nazi girl.

These are the things that affected me. I began to understand these engagements and commitments in terms of ordinary activities, as part of a way of life that was all too familiar to me. I, too, wanted to be a good girl. At the same time, reading Des Pres pushed me to reconsider what it meant to use mythic terms, "evil" or "monsters," to describe Nazis. I concluded that this language was utterly unhelpful. Des Pres helped me recognize how such claims made what happened not human, not within my reach, and so, somehow, safe. It could never happen again, because what had happened was all so exceptional. For me, this, again, was a way of avoiding the all-too-human legacy of the Holocaust. 


\section{Awkward Transitions}

In what I have just written, I find myself thwarted by a desire to get back to a time when my own life was not yet scarred, that time before I fully understood in my own body what it meant to be traumatized. And, like Ann Cvetkovich, who hopes that trauma discourse will allow her "to ask about the connections between girls like me feeling bad and world historical events," I find it hard to address the links between sexual trauma and these larger legacies. I am overwhelmed by the incongruity of the connections I am drawing between my own experience of sexual trauma and what I have read about the Holocaust. I want to try to get at what it was like before - what I thought and what I felt as I read these works before I was raped. Like many who experience trauma, my life is split in two, before and after. It is always difficult for me to touch what came before. It is hard not to reread the past knowing already what came after, and yet it is precisely to this task that I keep finding it necessary to return. I have done most of my work on the Holocaust, most of my reading, teaching, thinking, and writing, since I was raped. And yet, as I begin writing, I still want to find some less charged ground. I want to return to the time before I was raped, so as to justify my position, to find some less exposed, less visceral, less embarrassing and shameful way of positioning myself — but, like Cvetkovich, I cannot.

Given this, what I want to write about is what it continues to feel like, reading, viewing, and seeing Holocaust art, film, and literature. I want to talk about what draws me to some of these works again and again. ${ }^{9}$ And it is as a survivor of rape that I find these materials most compelling. I say this even though I find it hard to measure up to the devastation of the Holocaust, having myself "only" experienced the trauma of a sexual assault. I find myself struggling with the notion that my rape is not catastrophic enough to warrant these associations. These doubts have been so strong that even as I make these connections, the taboo lingers. The doubts keep creeping in, becoming in and of themselves a part of my critical engagement.

\section{The Compulsion and Shame of Visibility}

The first time I found myself compelled to speak as a survivor of rape in a context devoted to the Holocaust was at the conference "Representing the Holocaust: Practices, Products, Projections," which became the impetus for 


\section{Laura Levitt}

the collection I co-edited, Impossible Images: Contemporary Art after the Holocaust. ${ }^{10}$ I was sitting near one of the survivor artists in the audience, keenly aware of his presence and that of other survivors. I felt connected to them. What pushed me to speak was the use by one of the presenters of a series of classical artistic images of rape. To me, it seemed that his display of these images had little to do with the Holocaust or his broader argument, and I resented their inclusion. Their display felt unnecessary and became distracting. I was so uncomfortable with the analogy that I lost the train of his argument. Instead, I heard Irena Klepfisz's powerful words in the back of my head, aimed at an American audience all too willing to commodify the Holocaust for its own entertainment: "You're fucking around with my pain."11 I was so unnerved that in this instance, I felt nothing else. My pain was fucked with, and even as I edit these words, I am aware of the ways my understanding, my engagement, my notion of what it has meant for me to have survived rape is informed by an identification with Holocaust survivors, as complicated as all of this is.

I find this hard to say. I don't feel like ... I am not sure how to say this, although I know that I am deeply indebted to the writing of survivors, to their artistic production, and to that of other sympathetic witnesses. I feel unworthy. I still cannot fully accept that it is all right for me to see what happened to me in relation to these catastrophic events, to what individual survivors went through. I feel unworthy; my own story feels so minor, so small in comparison. This discomfort is at the heart of my critical engagement.

\section{Another Story}

Itka Zygmuntowicz, the survivor whose tale is retold with the help of Sara Horowitz in Four Centuries of Jewish Women's Spirituality, ${ }^{12}$ not many pages away from my own account of going to the mikvah to perform a ritual of at least partial healing after I was raped, ${ }^{13}$ also haunts these musings. When I first taught my graduate seminar on Holocaust and representation, ${ }^{14} \mathrm{I}$ invited both Itka and Sara to come to the class. I drove Itka home after that visit, after over two hours of hearing her stories, listening to her address my class, hearing my students' responses, and feeling our collective discomfort, especially as she asked for questions after her presentation, only to be met, initially, with silence-a silence I felt obliged to interrupt for her sake. It was after these 
very intense and powerful few hours that I found myself alone with Itka, driving through the unfamiliar and undifferentiated landscape of northeast Philadelphia.

In the contained space of my car-and it is not as if I haven't written and rewritten this story for myself again and again over the past few years-Itka told me that she had read my piece in Four Centuries and that she was sorry this had happened to me. ${ }^{15}$ Even writing this now, I can hardly stand remembering. No, I find myself reliving the discomfort that I felt then. How could she be comforting me? How could she recognize my pain, when what had happened to her was so much greater: longer, more terrifying, and more horrible? I could hardly take it. I was so taken aback, I didn't know what I felt. My reaction was, as it remains even now, a sense that it was not for her to comfort me; my pain could not, did not stand up against the Holocaust. And although intellectually and, to some extent, emotionally I know that this does not make sense, that it is not a position or a stance that I want to advocate, it was my gut reaction. It is precisely this reaction that fuels my discomfort now, as I contemplate sharing what it is that draws me to Holocaust material in the present and, more specifically, what it is that I have to say in my own voice about some of these works.

Upon reflection, I ask myself what could be more powerful an acknowledgment of Itka's position in the present than to be able to offer comfort to someone else who has suffered? Isn't this, in the simplest terms, the starkest terms, why at least some survivors have chosen to share their stories? For some, isn't there the hope that they will be able to help others who have not experienced what they have? I know that this was part of my own motivation for writing about my rape in my book and in an essay on silences around rape that I published in Fireweed, a feminist journal, ${ }^{16}$ and also why I wrote the piece that was published in Four Centuries. ${ }^{17}$

I began the present essay as a way of figuring out what I had to contribute to the introduction to Impossible Images. ${ }^{18}$ Even as Shelley Hornstein, Larry Silberstein, and I talked about inviting readers to respond to contemporary works of art with the help of critical essays that demonstrate various kinds of specific engagements with some of these works, I found it hard to own my own engagement. I still feel deeply exposed, afraid that readers will dismiss what I have to say. ${ }^{19} \mathrm{I}$ am afraid that readers will look at my words and think that I have flattened the differences between my own experiences and the Holocaust. I am afraid that my words will be considered too personal, too 


\section{Laura Levitt}

unprofessional or unscholarly. I am afraid of being accused of "playing my trump card." ${ }^{20}$ I really do hate writing these things, I wouldn't dream of saying them about someone else, but I feel keenly critical about myself. I know how uncomfortable it makes others to talk of personal trauma, to make such stories known, and, again, I sit here knowing that this is, at least in part, the risk Holocaust survivors take each time they tell their stories, as they make art and literature and allow their narrations to be filmed and archived. My experiences of speaking out, of writing about having been raped, are imbricated with my knowledge of these others' stories, the stories of survivors. I am indebted to them and don't know how to say this without calling attention to the specifics of my own story. And yet, how am I to honor them if I do not let myself say these things?

What I have to say also has broader implications. And I do know that this is important. Various kinds of work on the Holocaust have spurred other kinds of writing. They have inspired writers to confront and engage with other historical legacies of loss, of mass destruction and degradation ${ }^{21}$ - but they have also demanded something else. They have allowed people to make connections between Holocaust materials and much less dramatic and traumatic legacies of loss. This is what Cvetkovich's book, An Archive of Feelings, is all about. In a way, these experiences opened my eyes to other kinds of open wounds, other kinds of losses and their reverberations.

Let me begin here where I wanted to begin, with my first-person voice.

When I began reading first-person memoirs, Holocaust literature, and criticism as a graduate student, the year before I was raped, I read a review by Israeli literary critic Gershon Shaked of Saul Friedländer's memoir, When Memory Comes. ${ }^{22}$ I can no longer remember my initial responses to this review. I hardly remember actually reading it. Nevertheless, it is this review, more precisely its opening paragraphs, that held and sustained me after I was raped. I was drawn to the image of Gershon Shaked, the great scholar of Hebrew literature, as a nine-year-old boy in Vienna, alone in his family's apartment as the storm troopers entered and not only destroyed this place that was his home, but deeply wounded his body in ways he still cannot fully remember.

On 10 November 1938, a nine-year-old boy was alone in a large apartment on a respectable street in Vienna. His mother had gone out. His father had 
been deported to a concentration camp in April. The boy did not know that there was rioting outside. Sensing the approaching dusk by the shadows on the lofty walls, he crawled under the piano in a corner. To calm his fears he played. He tried to take refuge in fantasy; but his fear overwhelmed him. There was shouting on the floor above. He turned on all the lights and set two chairs against the front door. Soon there was knocking. The boy was afraid to open the door. When the men came bursting in he did not know where to hide. None of the tricks he had learned from his books were of any help. Finally, he crawled back under the piano.

The boy never saw the men's faces, only their five pairs of boots. Taking no interest in him, they emptied the apartment of its contents - rugs and paintings, silver, and finally furniture, piece by piece. It was only when they turned to the piano that they noticed the child clinging to one of its legs. They worked him over with their boots; they said and did things that the boy does not want to remember.

When it was all over, the boy curled up within himself, surrounded by the bare walls of the now empty apartment. He could not turn on the lights because the raiders had taken all the bulbs. ${ }^{23}$

This is not the full passage from Shaked's text. I end my citation where my engagement with the review ends and my own imaginative rereading of the text begins. I was drawn to the little boy whose imagination could not ultimately protect him from the devastation of physical assault and the brutal usurpation of his family's home and property. It is the horror of these combined violations that is so devastating for Shaked and forces him to let go of the life he has known. The text continues: "Huddled in that darkness, mortified and alone, the boy discovered his own private kind of Zionism. How different it was from the Zionism of those pioneers in the sunny fields of the Jezreel Valley." 24 In the enforced darkness of the now emptied apartment, the battered boy formulates a response not only to the horrible disappointments embedded in the cultural promises and pretensions of this home, but also to the violation of his body. It is here that Shaked lets go of his European identity and posits a new one.

I don't want to go there. The little boy taking shelter under the piano, trying to tell himself stories, to take comfort in fantasy and the play of his imagination, is what interests me. Although the little boy ultimately is unable to find protection in this retreat, the piano and his imagination do offer him some sort 


\section{Laura Levitt}

of comfort and protection, if only temporarily. For a brief moment, he is safe under the piano's shelter; for a time, he is able to tell himself stories to assuage his fears. Ultimately he learns that these cultural vestiges cannot protect him from the men who have come to destroy this life. Despite this, nevertheless, this same little boy grows up to become a scholar of literature. He devotes his life to the creation of a Hebrew literary canon. He makes a new life out of the stuff of imagination and cultural productions. This contradiction is what returned to me over and over again in the days and weeks following my rape. I kept returning to that devastated little boy who would become a great man of letters even though words and stories and even the physical presence of an instrument as monumental as a piano could not protect him when he was most vulnerable. I needed this story. It kept reminding me that I, too, could survive an assault on my home and my body. There would be a life after. It also reminded me that such a life need not erase the memory of disappointment, of vulnerability, and of violence. Those memories need not go away even in the subsequent labor of cultural production. There would still be a place for imagination.

What made this real for me were the various reiterations of the story, the telling and retelling I performed in my head at various moments when the thought of going on felt much too difficult. At those odd moments, while driving in my car, sitting in the middle of a meal, or as I tried to fall asleep at night, I would remember the little boy who hid under the piano, the boy whose stories, whose imagination could not protect him. And I would remind myself that despite this experience, that same little boy would devote himself precisely to the work of imagination. He had not given up on imagination. Knowing its limitations had not made him forsake the imaginative.

As I try to write this out, I find it increasingly difficult to pinpoint what about the story was so important. It was never just the story; rather, it was all the resonances of this tale that comforted me. I am grateful to Shaked for recounting this moment and writing it down. The rest of the review never really interested me; I still do not agree with Shaked's reading of Friedländer's memoir. I was never invested in the particular form of Zionist cultural production that has been Shaked's life work. Nevertheless, I admire his passion. I admire the life that he has made for himself after devastation. 


\section{Another Connection}

Only after transcribing the passage from Shaked's text, writing about it, and rereading what I had written did I notice the date. Shaked writes about the evening of "November 10, 1938." I am not sure how to write this without it sounding trite, and yet I need to say something about this date. It has been over twelve years since I was raped, and yet each and every year, as the days get shorter and the air gets cooler, I know in my body that the anniversary of my rape is approaching. I was raped on the first Tuesday of November, 1989. Although I could look up the exact date, I have found myself thinking about the anniversary in very American terms. I was raped on Election Day. That is how I have thought about the anniversary from the beginning. Even in 1993, as my father ran for elected office, as we waited for the election results, I was keenly aware that this was the anniversary of my rape. This was the same week in 1989 that the Berlin wall came down; just days after I was raped, I watched as CNN played live broadcasts from Berlin. In 1989, that Tuesday fell in the same week that Jews in Atlanta and around the world commemorated Kristallnacht and simultaneously worried about a newly unified Germany and what it might mean for the future. It was all somehow unreal. My world had changed dramatically, and I was not alone. For me, these geopolitical changes and their over-determination, their occurrence on the anniversary of Kristallnacht, their relation to an American election day, will all always be imbricated with having been raped. I will never be able to consider these events in isolation. For me, they will always resonate with each other and now with Shaked.

Like Shaked, I was violated in early November. The actual date was the eighth or ninth of November, but my resistance to attaching the memory to a specific date has made me feel even more connected to "November 10, 1938," the date Shaked writes about. And yet I did not consciously realize this particular association to Shaked until I copied his words and reread them in the context of this writing.

\section{Some Final Thoughts}

I am afraid that what I have written sounds too easy or too simple, naïve, or too redemptive; ${ }^{25}$ or perhaps I do not really want to confront the extent to which I am invested in imagining Shaked's narrative as being more about the fact that 


\section{Laura Levitt}

he survived than about the terror he experienced. I was especially drawn to the notion that he had been able once more to celebrate the imagination, despite his traumatic experience and, more specifically, despite the incapability of his imagination to protect him during that terrible night. As a graduate student who wanted to believe that I, too, could continue the life I was just entering, a life with texts, this part of the story, I now realize, was crucial.

I need to say again how meaningful Shaked's narrative was for me, how much courage and hope it provided me in the most vulnerable period of my life. I am embarrassed, and yet I want to acknowledge this, my relationship to a very specific Holocaust text, to help explain the urgency, the depth of my own engagement with these materials. I want to be clear that powerful things can happen when we read, write, and engage with the works of creative artists and, in this case, scholars and critics who tell stories, who offer glimpses of their own engagements with terror, with loss, with the devastation of a life destroyed, a home unmade.

In part, I tell this story to say that words and images matter, that they have unpredictable effects. Reading and viewing are particular. Not all of us will approach a specific image or text in the same way. An individual will notice a telling detail, the repetition of a certain figure, and make a connection to her own life, marking its difference from and association with a particular image or narrative of her own. It may be that the ordinary images and the literary and artistic works I read and view alongside them will register in ways I cannot begin to know. ${ }^{26}$ Like my reading of Shaked's review, perhaps one of the images or stories I have described here will return to a reader when she needs it. Maybe another passage will shake a different reader out of some complacent view that he or she took to be just the way things are. For me, these kinds of affective engagements matter. They help us gain access to the archive of feelings that are themselves a very powerful legacy of the Holocaust.

What this kind of more intimate engagement also offers, especially to those of us who are increasingly more distant from the Holocaust, those with no direct familial connections, in the present, to survivors and to those who died, is a way of remembering that survivors are, despite all that they have been through, very much like us. What I have learned is that to forget this most basic truth in the effort to find larger lessons is to make their losses less real. As Irena Klepfisz, a child survivor, reminds those of us who, like me, are a part of the growing community of Jews whose relationship to the Holocaust is increasingly distant and mediated, 
Whatever the long-term effects on descendants of European Jews, whatever the effects on Jewish history and the history of humankind, for survivors der khurbn will remain an individual, personal experience. It permanently changed and shaped our lives.

Perhaps this is obvious. And yet, I sometimes think that this most obvious fact is often forgotten in the whirl of rhetoric and research by political scientists and historians. Too frequently the Holocaust is spoken of in statistics, in analysis of power and powerlessness, too often evoked by photographs of lines of anonymous naked men and women or mass graves. Yet der khurbn that survivors experienced is not general but very specific. It is reflected in precious sepia photographs pasted in incomplete family albums. It consists in identifiable names of familiar faces of family members, of named streets, stores and schools, teammates, friends, libraries, doctors, hospitals, lectures, marches, strikes, political allies and enemies - the people, places and institutions that make up the fabric of any human being's ordinary, everyday life. ${ }^{27}$

Although it remains important to consider questions of power and its abuses, or what Klepfisz describes as "issues of power and powerlessness," to gather statistics and continue the more formal archival work of clarifying the numbers, the dates, and the places of horror that are the Holocaust, these are not the only tasks that deserve critical attention. Like survivors and the families of survivors, the rest of us, too, need to remember that we are implicated in the legacy of the Holocaust. It touches us. It leaves emotional traces that have shaped all kinds of relationships in the present. These, too, need to be archived or otherwise accounted for. Art and literature help us to make these connections. Works of imagination help us clarify the very specific ways that the Holocaust continues to both haunt and animate our everyday lives in the present.

\section{Notes}

I want to thank Catherine Staples for her careful reading of various versions of this essay and for her many thoughtful and powerful suggestions and comments. I also want to thank Deborah Greniman for her thoughtful, critical, and engaged reading of this essay. Her suggestions and those of Marian Ronan at the final hour have made this a stronger essay. Finally, I want to thank Laurence Silberstein and Shelley Hornstein for encouraging me to write about these things in the first place. 


\section{Laura Levitt}

1. Irena Klepfisz, A Few Words in the Mother Tongue: Poems Selected and New 1971-1990 (Portland, Ore.: Eighth Mountain Press, 1990), pp. 184; 185-186.

2. Ann Cvetkovich, An Archive of Feeling: Trauma, Sexuality, and Lesbian Public Culture (Durham and London: Duke University Press, 2003), p. 3.

3. Shimon Attie, Sites Unseen: European Projects-Installations and Photographs (Burlington, Vt.: Verve Editions, 1998).

4. Terrence Des Pres, The Survivor: An Anatomy of Life in the Death Camps (New York: Oxford University Press, 1976).

5. Here I am indebted to Roger Simon for helping me appreciate the centrality of melodrama as an expectation in terms of what readers and viewers have come to expect in such works. Roger Simon's plenary address, "The Audio-Visual Supplement of Holocaust Survivor Video Testimony," was given at the conference "The Fading Image: Visual Culture and the Transformation of Memory," held at the Center for the Study of Historical Consciousness, University of British Columbia, Vancouver, Canada, on May 16-17, 2003. I also greatly benefited from informal conversations with him and from his comments on my paper "Secret Stashes: The Recovery of Family Photographs and American Jewish Identity." These are difficult distinctions to make. I in no way want to take away from the powerful narratives of survivors who resisted the Nazis in any number of ways. I also want to suggest that the kinds of moves Des Pres makes to take into account the quotidian as a site of resistance echo the moves made by Katie Cannon in a radically different context. Cannon makes it clear that African American women slaves in the United States resisted their enslavement and dehumanization in myriad small and daily acts. Here, too, resistance was not only about armed and dramatic acts. See Katie Cannon, Black Womanist Ethics, (Atlanta: Scholars Press, 1988).

6. Alice Miller, For Your Own Good: Hidden Cruelty in Child-Rearing and the Roots of Violence (New York: Farrar Straus Giroux, 1984).

7. Christa Wolf, Patterns of Childhood (New York: Farrar Straus Giroux, 1976).

8. Cvetkovich, Archive of Feeling (above, note 2), loc. cit.

9. Here I have in mind Barthes's notion of the punctum, the unique gesture, moment, or segment that pierces us, gets under our skin, and literally touches us. See Roland Barthes, Camera Lucida: Reflections on Photography (New York: Hill and Wang, 1981).

10. Shelley Hornstein, Laura Levitt, and Laurence Silberstein (eds.), Impossible Images: Contemporary Art after the Holocaust, (New York: New York University Press, 2003). The conference was held at Lehigh University, Bethlehem, Pa., on May 21-23, 2000.

11. Irena Klepfisz, "Resisting and Surviving in America," in Evelyn Torton Beck (ed.), Nice Jewish Girls: A Lesbian Anthology (Boston: Beacon Press, 1989), p. 117: 
So you can understand that when I see that experience [of Holocaust survivors] exploited, co-opted, when I sense people are fed up, how I want to rage at everyone: "You're fucking around with my pain, with my real pain, my real life. Forget the metaphor. Think about reality."

12. Itka Frajman Zygmuntowicz with Sara Horowitz, "Survival and Memory," in Ellen Umansky and Dianne Ashton (eds.), Four Centuries of Jewish Women's Spirituality: A Sourcebook, (Boston: Beacon Press, 1992), pp. 286-290.

13. Laura Levitt and Sue Ann Wasserman, "Mikvah Ceremony for Laura," ibid., pp. 321-326.

14. This was an extraordinary class. Among the students were Michelle Friedman, Tania Oldenhage, Claudia Schippert, and Liora Gubkin, three of whom wrote their dissertations on Holocaust-related topics that were initially developed in the class, and all of whom have taught and developed courses of their own on the Holocaust.

15. After this excursion I returned to Temple University to see some of experimental film-maker Abe Ravett's films for the first time, and I met Ravett. All of these powerful things feel compressed, and they really were, both physically and temporally. I write about Ravett's "Half-Sister" in the first section of my forthcoming book, Ordinary Jews. I have also shown these films at various academic conferences and presentations between 1995 and the present.

16. Laura Levitt, Jews and Feminism: The Ambivalent Search for Home (New York: Routledge, 1997), and "Speaking Out of the Silence Around Rape: A Personal Account," Fireweed, 41(Fall, 1993), pp. 20-31.

17. Here I have in mind the kind of intimacy that Svetlana Boym refers to in her work on nostalgia as "diasporic intimacy," in idem, The Future of Nostalgia (New York: Basic Books, 2001). In this case the following passage comes to mind although the effect is a bit different. Unlike Boym, I was more uncomfortable with the connection and less delighted by the intensity of the surprise:

Diasporic intimacy is belated and never final; objects and places were lost in the past and one knows that they can be lost again. The illusion of complete belonging has been shattered. Yet, one discovers that there is still a lot to share. The foreign backdrop, the memory of past losses and recognition of transience do not obscure the shock of intimacy, but rather heighten the pleasure and intensity of surprise. (p. 255)

18. Above, note 10. I thank my co-editors, Shelley Hornstein and Laurence Silberstein, as well as Tania Oldenhage and Deborah Glanzberg-Krainin for encouraging me to write about these things as a way into that book and into my current book project (personal correspondences, Spring 2001). 


\section{Laura Levitt}

19. Here I have in mind the powerful account of such dismissal described by Linda Alcoff and Laura Gray in "Survivor Discourse: Transgression or Recuperation?" Signs, 18 (1993), pp. 83-101.

20. This phrase comes from a conversation I had after presenting a portion of what was to become the introduction and first chapter of my book Jews and Feminism. In the presentation, I had spoken about how my notion of home was viscerally destroyed by my experience of being raped in my apartment in Atlanta in November of 1989. The feminist scholar who made this comment suggested that I could only tell this story once for it to have any effect. My book and much of my subsequent writing is a refutation of that claim. In all of these works I have argued that we need to tell and retell these stories in different ways precisely because they are continually being reabsorbed into our lives. Trauma remains a part of who we are in an ever-shifting present, in which its meanings can and do change over time. The conference where this conversation took place was held at Iliff School of Theology in Denver, Colorado, in the Fall of 1994. It became the basis for Rebecca S. Chopp and Sheila Greeve Davaney (eds.), Horizons in Feminist Theology: Identity, Tradition, and Norms (Minneapolis: Fortress Press, 1997), which includes an edited version of my presentation, "Becoming an American Jewish Feminist" (pp. 154-164).

21. Here I am thinking of a conversation at Michelle Friedman's dissertation defense (Bryn Mawr College, January 2001) about Toni Morrison reading Elie Weisel and how her engagement with Weisel might, at least in part. have enabled her writing about slavery, her efforts to re/member a different haunting legacy.

22. Saul Friedländer, When Memory Comes (New York: Farrar Straus Giroux, 1979). 23. Gershon Shaked, The Shadows Within: Essays on Modern Jewish Writers (Philadelphia: Jewish Publication Society, 1987), p. 181.

24. Ibid., pp. 181-182

25. For more information on anti-redemptive narratives and the Holocaust, see James Young, At Memory's Edge: After-Images of the Holocaust in Contemporary Art and Architecture (New Haven: Yale University Press, 2000). See also J. Liora Gubkin's rereading of contemporary Passover Haggadot and the inclusion of Holocaust materials in that quintessential of redemptive narratives, "You Shall Tell Your Children: Remembering the Holocaust in American Passover Haggadot" (Ph.D. Dissertation, University of Southern California, August 2001).

26. This is the approach I take in my current book project, Ordinary Jews, which uses family photographs to peer out from under the shadow of the Holocaust in order to reclaim some of the stories of American Jews from the early part of the twentieth century. Each section of the book juxaposes images and texts associated with the Holocaust with ordinary images from a single American Jewish family. It uses the formal connections between images and narratives as a way into the work of identification 
and distinction that has made engagement with these other narratives so difficult. I use as my starting point contemporary American Jews' fascination with family images of European Jews whose lives were lost or scarred by the Holocaust.

27. Irena Klepfisz, Dreams of an Insomniac: Jewish Feminist Essays, Speeches and Diatribes (Portland, Ore.: Eighth Mountain Press, 1990), p. 133. 